PNL-7684

UC-602

\title{
ISV Safety, Processing, and Starter Path Issues
}

\author{
Compiled by: \\ D. K. Hilliard \\ C. H. Kindle
}

April 1991

Prepared for the U.S. Department of Energy under Contract DE-AC06-76RLO 1830

Pacific Northwest Laboratory

Operated for the U.S. Department of Energy

by Battelle Memorial Institute 


\title{
DISCLAJMER
}

This report was prepared as an account of work sponsored by an agency of the United States Government. Neither the United States Government nor any agency thereof, nor Battelle Mernorial Institute, nor any of their employees, makes any warranty, expressed or implied, or assumes any legal liability or responsibitity for the accuracy, completeness, or usefulness of any information, apparatus, product, or process disclosed, or represents that its use would not infringe privateiy owned rights. Reference herein to any specific commercial product, process, or service by trade name, trademark, manufacturer, or otherwise does not necessarily constitute or imply its endorsernent, recommendation, or favoring by the United States Government or any agency thereof, or Battelle Memorial Institute. The views and opinions of authors expressed herein do not necessarily state or reflect those of the United States Government or any agency thereof.

\author{
PACIFIC NORTHWEST LABORATORY \\ operated by \\ BATTELLE MEMORIAL INSTITUTE \\ for the \\ UNITED STATES DEPARTMENT OF ENERGY \\ under Contract DE-ACO6-76RLO 1830
}

Printed in the United States of America

Available to DOE and DOE contractors from the

Office of Scientific and Technical Information, P.O. Box 62, Oak Ridge, TN 37831; prices available from (615) 576-8401. FTS 626-8401.

Available to the public from the National Technical Information Service, U.S. Department of Commerce, 5285 Port Royal Rd., Springfield, VA 22161. 
PNL-7684

UC -602

ISV SAFETY, PROCESSING, ANO STARTER PATH ISSUES

Compiled by:

D. K. Hilliard

C. H. Kindle

\section{ApriT 1991}

Prepared for the U.S. Department of Energy under Contract DE-ACO6-76RLO 1830

Pacific Northwest Laboratory

Richland, Washington 99352 



\section{SUMMARY}

Numerous experiments and studies related to safety concerns in the in situ vitrification (ISV) process have been conducted at Pacific Northwest Laboratory. Topics of interest include 1) combustible inclusions, 2) sealed containers, 3) radiant heat surge, 4) electrical shock, 5) general risk analysis, and 6) Pu criticality. The data and analyses are those used for the initial ISV development and subsequent improvement; the majority was performed in 1987 or earlier. The purpose of this report is to document these analyses for reference purposes; knowledge gained more recently is, or will be, incorporated in other documents.

Combustible materials within the vitrification zone are pyrolyzed into combustible gases at the high temperatures in the ISV melt. The most serious safety concern from this sudden gas generation is the possibility of exceeding the off-gas system capacity. The off-gas system of the large-scale system is designed for solid combustible concentrations of not more than $3,200 \mathrm{~kg} / \mathrm{m}$ of depth per setting and a single combustible volume limit of $0.9 \mathrm{~m}^{3}$. It is designed to accommodate organic 1 iquid combustible components from 700 to $4800 \mathrm{~kg} / \mathrm{m} / \mathrm{setting}$ ( $50 \mathrm{~kg}$ if in a sealed container).

Sealed containers can build up pressure as the temperature increases. When the container is breached, gases escape to the hood over a very short time period (approximately $2 \mathrm{sec}$ ). The rapid change in color as the dark "cold cap" melts during gas releases in normal ISV processing increases the radiant heat flux into the off-gas hood in a matter of seconds. It is hypothesized that under certain conditions this radiant heat surge combined with the evolved and combusting gases could expand the gas volume enough to overload the blower capacity.

Voltages up to $4160 \mathrm{~V}$ and currents up to $4000 \mathrm{~A}$ are used in the ISV process. The potential for generating stray voltages or currents to nearby facilities or underground service lines is very small, however, because 1) the process employs an isolated electrical power suppiy; 2) the system's 
characteristics make it a poor transmitter of induced voltages; and 3) numerous electrical safety precautions are observed while testing and operating the ISV system.

Safety analyses have been conducted for a conceptual design example site, a reference site, and a specific large-scale vitrification site. Maximum exposure during routine operation is expected during electrode emplacement. The doses calculated for ISV operation at the reference site are substantially below the DOE regulations on exposure for routine operations to both workers and the general public. Analyses of accident scenarios, equipment failures, and other potentiai hazards for the sites considered indicate an acceptable level of risk. Assumptions made for risk analyses at these specific sites may not be directly valid for any new sites where the ISV technology is applied. It is therefore prudent that a site-specific assessment be completed for any site where a demonstration is planned.

The possibility of a criticality occurring in the melt or off-gas system during in situ vitrification of a Pu-contaminated waste site has been considered since the beginning of the ISV program at PNL. A7though experimental work has been 1 imited, and further engineering- and pilot-scale tests are recommended, no credible concentration mechanism has been identified for ${ }^{239} \mathrm{Pu}$ or other transuranic fissionable isotope. Other criticality concerns evaluated include 1) pyrolysis, 2) changes in the neutron reflection/ absorption properties of the soi], and 3) densification of moderating materials that have higher hydrogen density than water. The operating limits for ISV will be met if the setting to be vitrified contains a total Pu mass less than $0.6 \mathrm{~kg} \mathrm{Pu}$ (33\% safety factor applied to $1.7 \mathrm{~kg}$ calculated limit) or has an areal concentration of less than $1.0 \mathrm{~kg} \mathrm{Pu} / \mathrm{m}^{2}$ (33\% safety factor applied to $2.9 \mathrm{~kg} / \mathrm{m}^{2}$ calculated limit) with no possibility of concentration. The areal concentration limit is $0.8 \mathrm{~kg} / \mathrm{m}^{2}$ when large quantities of hydrogenated organic materials such as polyethylene are present with $\mathrm{Pu}$ in waste drums or other high-integrity containers.

Although formation of a "starter path" of conductive material between electrodes does not pose a serious safety hazard, the geometry, composition, and amount of material in the path are factors in an effective startup. 


\section{ACKNOWLEDGMENTS}

The compilers acknowledge the additional ISV staff members who conducted the experiments and studies, wrote source documents, and reviewed this document. Those additional staff actively involved in the preparation of various sections of this document include the follow:

Combustible Inclusions and Sealed Containers: R. K. Farnsworth and

J. L. Buelt

Electrical Shock: J. L. Buelt

Risk Anatysis: D. A. Lamar

PJutonium Criticality: R. A. Libby, R. K. Farnsworth, and J. L. Ryan 



\section{CONTENTS}

SUMMARY ..................... . $i$ i

ACKNOWLEDGMENTS ...................

INTRODUCTION .............................. 1

OVERVIEW OF THE ISV PROCESS ................ 1

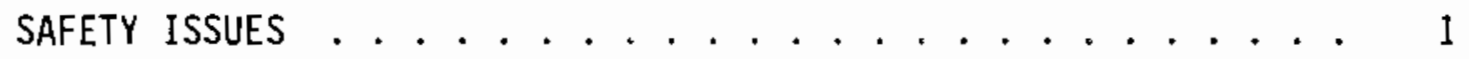

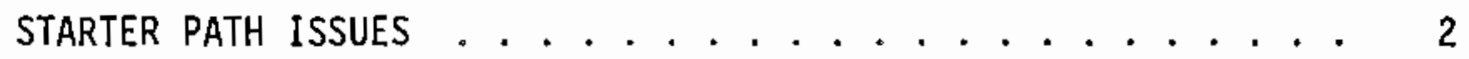

COMBUSTIBLE INCLUSIONS ................ 3

EFFECTS OF GAS RELEASES FROM COMBUSTIBLE INCLUSIONS ..... 3

EFFECTS OF GAS RELEASES ON OFF-GAS SYSTEM .......... . . 3

CALCULATED PROCESSING LIMITS ............... 5

SUMMARY OF TEST RESULTS ................ 8

SEALED CONTAINERS ................... I1

MAXIMUM GAS RELEASE RATE FOR VARIOUS GEOMETRIES OF

SEALED CONTAINERS ..................... 11

SUMMARY OF TEST RESULTS ................ 12

RADIANT HEAT SURGE ........................ 15

ELECTRICAL SHOCK .................. 17

ELECTRODE BUS HAZARD ............... 17

STRAY VOLTAGE HAZARD ...................... 17

RISK ANALYSIS ......................... 19

CALCULATED EXPOSURES AT A REFERENCE SITE . . . . . . . 19

SAFETY ANALYSIS FOR CONCEPTUAL DESIGN . . . . . . . 23

SAFETY ANALYSIS FOR LARGE-SCALE VITRIFICATION AT

A SPECIFIC SITE ........................ 26

PLUTONIUM CRITICALITY . . . . . . . . . . . . 31 
FISSILE ISOTOPES ......................... 31

PLUTONIUM CONCENTRATION MECHANISMS .................. 31

OTHER CRITICALITY CONCERNS . . . . . . . . . . . . . . . . 35

PLUTONIUM MASS AND AREAL CONCENTRATION LIMITS FOR ISV . . . . 37

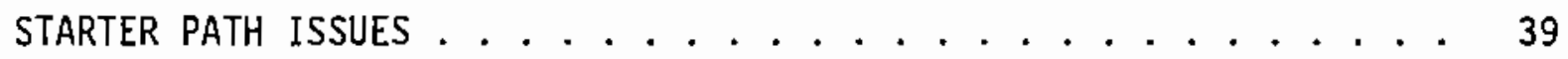

RANGES OF STARTER PATHS USED ................... 39

CURRENT PREFERRED PATHS ...................... 41

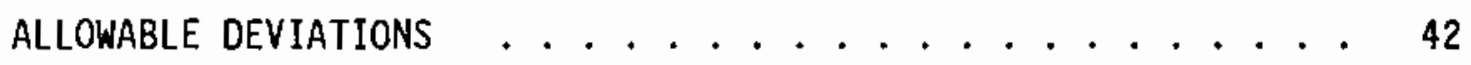

RESTART ............................. 42

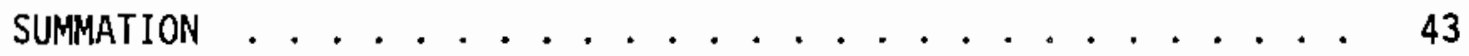

REFERENCES .................... . . 45 


\section{FIGURE}

1 Cross-sectional view of Starter Path .......... 40

\section{TABLES}

1 Calculated Release Rates from Sealed Metal Containers ..... 11

2 Can Contents Release Data ............... 13

3 Whole Body Radiation Doses from Routine Operations . . . . . 20

4 Public Dose Comnitments from Routine Operations ....... 20

5 Occupational Doses from Accidental Releases . . . . . . . 22

6 Public Dose Commitments from Postulated Abnorma] Occurrences . 23

7 Public Dose Commitments for Far-Term Intrusion, rem . . . . . 24

8 Estimated Subcritical Mass Limits for Various Fissile and Non-Fissile Nuclides . . . . . . . . . . . . 32

9 Minimum Critical Mass of Plutonium in Water-Saturated Soir . . 37 



\section{INTRODUCTION}

In situ vitrification (ISV) is being developed by Pacific Northwest Laboratory $(P N L){ }^{(a)}$ for the U.S. Department of Energy. It is an electrically powered thermal treatment process that converts contaminated soil into a chemically inert and stable glass and crystalline product.

\section{OVERVIEW OF THE ISV PROCESS}

In the ISV process an electrical potential is applied to the electrodes to establish current, and the resultant power heats and melts the soil to operating temperatures of $1600^{\circ} \mathrm{C}$. As the molten zone grows, the vitrified mass incorporates any radionuclides and nonvolatile hazardous elements, such as heavy metals, that may be present. The high temperature of the process destroys organic components by pyrolysis. The pyrolized byproducts migrate to the surface of the vitrified zone, where they combust in the presence of air. A hood placed over the area being vitrified directs the gaseous effluents to an off-gas treatment system, if necessary. Both chemical and radioactive contaminants are destroyed or immobilized with no need for disposal.

When the process is completed, the molten volume cools producing a block of glass and crystalline material that resembles natural obsidian commingled with crystalline phases. The product passes Environmental Protection Agency leach resistance tests (EPTOx, TCLP), and it can be classified as nonhazardous from a chemical hazard perspective.

\section{SAFETY ISSUES}

Safety concerns related to vitrification of contaminated soils and buried wastes include 1) the effects of combustible materials or sealed containers in the vitrification zone, 2) radiant heat surges that might increase the gas volume in the hood beyond design limits, 3) the possibility of electric shock, 4) the possibility of creating a criticality, and 5) a wide range

(a) Operated for U.S. Department of Energy by Battelle Memorial Institute under Contract DE-ACO6-76RLO 1830. 
of potential risks resulting from the presence of radioactive and hazardous materials, high temperatures, and experimental equipment. Safety problems have not occurred in these areas to date. Nevertheless, even unijkely scenarios and extreme conditions must be evaluated to ensure that design criteria and operating limitations are adequate to protect the health or safety of workers or the public.

Numerous experiments and studies related to these safety concerns have been conducted at PNL. Most of the work was conducted in the early 1980s. Results from these tests and studies have been summarized and integrated in this report to delineate the scope of safety studies already performed by PNL. The purpose of the document is to provide one easily accessible source for obtaining information that was previously available only in a scattered assortment of unpublished memos and reports and as sections of published reports with much larger scopes.

\section{STARTER PATH ISSUES}

Various compositions and amounts of starter path material and several configurations of starter paths have been used in ISV experiments. The recommended starter path for each size system is described in the last section of this document. 


\section{COMBUSTIBLE INCLUSIONS}

During ISV of a waste site, any solid combustible inclusions within the soil are pyrolyzed into combustible gases at the high temperatures of the melt. Engineering- and pilot-scale tests with simulated combustible waste in a variety of containers indicated that combustible gas release is sporadic and may occur in a very short time period. The effects of these releases were considered in establishing the design of the hood and off-gas system.

\section{EFFECTS OF GAS RELEASES FROM COMBUSTIBLE INCLUSIONS}

Several effects of the gas releases from pyrolysis of combustible inclusions must be considered in establishing the design of the hood and off-gas system:

- The protective cold cap can be broken up as the gases are released, resulting in increased volatilization and heat losses.

- Gases may carry entrained hazardous species with them to the off-gas system. Such transport may al so present a potential criticality in the scrub system.

- Unburned combustible gases that are superheated in the molten zone burn in the hood plenum, creating flames and high peak temperatures.

- The gas generation rate may exceed the off-gas system capacity, causing pressurization of the containment hood and ejection of soil and molten glass from the vitrification zone.

\section{EFFECTS OF GAS RELEASES ON OFF-GAS SYSTEM}

The effects of combustible inclusions that have the greatest impact on the off-gas system are higher-than-normal gas generation rate and high peak temperatures. The capacity and heat tolerance of the off-gas system must be examined.

\section{Capacity}

The base capacity requirements of the large-scale off-gas system is $50 \mathrm{~m}^{3} / \mathrm{min}$, based on measured in-leakage around the hood of the pi\}ot-scale system (Buelt and Carter 1986). However, when combustibles are present, the 
combined flow of pyrotyzed gases and combustion air increases the required capacity. The magnitude of the undesirable effects of the gas releases is directly proportional to the rate at which pyrolyzed gases are generated and released. Engineering- and pilot-scale tests (ESLT-11, PSFT-3) have shown that combustible gas release is sporadic and may occur in a very short time period (Oma, Farnsworth, and Rusin 1982).

The maximum effluent rate from vitrification of the maximum concentration of solid combustibles is calculated as follows (Buelt and Carter 1986a):

$$
V^{\prime}=v \cdot(1 \cdot W \cdot p B) \cdot X \cdot 0.0038 / M W
$$

$$
\begin{aligned}
\text { where } V^{\prime} & \left.=\text { pyrolyzed gas generation rate (std } \mathrm{m}^{3} / \mathrm{min}\right) \\
V & =\text { melt velocity downward }(\mathrm{cm} / \mathrm{h}) \\
(1 \cdot \mathrm{w} \cdot \mathrm{pB}) & =\text { concentration of combustibles per meter depth }(\mathrm{kg} / \mathrm{m}) \\
X & =\text { mass pyrolyzed gas/mass solid (assume } 0.85) \\
M W & =\text { average molecular weight of pyrolyzed gases. }
\end{aligned}
$$

Based on the mathematical model that predicts large-scale processing behavior, the downward melting velocity in soil is $7 \mathrm{~cm} / \mathrm{h}$. Assuming a solid combustible with only $30 \mathrm{vo} 1 \%$ soil and a concentration of $3200 \mathrm{~kg} / \mathrm{m}$, the rate of pyrolyzed gas generation is $16 \mathrm{~m}^{3} / \mathrm{min}$. This assumes the me $7 \mathrm{t}$ processes combustibles at the same progression rate of melting soil $(7 \mathrm{~cm} / \mathrm{h})$. Further assuming that the solid wastes are chemically similar to wood, $5 \%$ of the gas generated would be noncombustible $\mathrm{CO}_{2}$ (Mudge et a1. 1980). This leaves $15.2 \mathrm{~m}^{3} /$ min of combustible gas. Using a $20 \%$ excess combustion air rate, and accounting for the combustion products and the noncombustible portion, the total effluent rate is $52 \mathrm{~m}^{3} / \mathrm{min}$. The off-gas system capacity of $104 \mathrm{~m}^{3} / \mathrm{min}$ at a maximum off-gas temperature of $750^{\circ} \mathrm{C}$ thus provides a safety factor of two.

If sufficient soil is mixed with the combustibles, the restrictive heat transfer due to the soil may prevent the rapid decomposition observed in the pilot-scale experiment PSFT-3. For such waste sites, a smaller off-gas system may be adequate. In situ vitrification of one section of a long burial trench or a wide burial pit may create underground burning of combustibles adjacent 
to the molten zone before wastes can be vitrified. Such burning would be slow because of limited oxygen but could bring hazardous species to the surface at the edge of the molten area. (a)

\section{Heat Tolerance}

The large-scale unit's functional design criterion is that the system must accommodate a combustible content of $3200 \mathrm{~kg} / \mathrm{m}$ of depth. When combusted and combined with natural heat losses, this amount is converted to an energy release rate of $12.8 \mathrm{milli}$ ion $\mathrm{Btu} / \mathrm{h}$. Accounting for heat losses from the hood and off-gas line, the maximum temperature and heat load of the off gas entering the processing trailer are expected to be $750^{\circ} \mathrm{C}$ and $5.3 \mathrm{million} \mathrm{Btu} / \mathrm{h}$, respectively.

Because of the high heat load that results from a large quantity of combustibles, a dual cooling system is being considered. It consists of a $1.9 \mathrm{miltion} \mathrm{Btu/h}$ secondary cooling system and a $3.4 \mathrm{million} \mathrm{Btu/h}$ in- 1 ine glycol heat exchanger. The latter unit may be bypassed when combustibles are absent.

Another design consideration resulting from the increased temperatures when combustible material is present is that the hood and off-gas line must be designed to operate at the high temperatures of the combustion gases and molten glass that may be ejected. In addition, the height of the hood should aiso be adequate to minimize the possibility of glass contacting the ceiling.

\section{CALCULATED PROCESSING LIMITS}

Processing limits have been calculated for solid combustible component volume, organic liquid combustible volume, maximum heat, maximum single combustible volume, and maximum single-void volume of a container (Buelt and Carter 1986). These limits are given in this section along with discussions of how they were calculated.

(a) These concerns predate the first field tests on buried waste. Based upon excavation of simulated buried waste pits after two pilot-scale ISV melts in 1990, a steep thermal gradient was maintained, lessening the risk of ignition a distance from the melt. 
Solid Combustible Component Limit

The off-gas system is designed for solid combustible concentrations of not more than $3,200 \mathrm{~kg} / \mathrm{m}$ of depth per setting if combustibles are distributed relatively evenly throughout the soil (minimum soil or other noncombustible content of $30 \mathrm{vol} \%)$. This capacity includes additional air added to the hood to maintain $20 \%$ excess combustion air and assumes that the peak combustion rate is twice the average (Oma et a1. 1983). The criterion is based on worstcase expectations for a burial trench where solid wastes are distributed and covered with soil. If less than 30 vol\% soil is distributed with the solid wastes, molten soil is assumed to advance through the combustibles and pyrolyze them in excess of design capabilities. In this case, the single combustible volume limit of $0.9 \mathrm{~m}^{3}$ must be met (single-volume limit discussed below).

\section{Organic Liquid Combustible Component Limit}

The reference off-gas system can accommodate organic liquid combustible components from 700 to $4800 \mathrm{~kg} / \mathrm{m} / \mathrm{setting}$ ( 1 to $7 \mathrm{wt} \%$ ), assuming the soil is consolidated with no sealed containers (e.g., drums or buckets). This range is based on gas flow and heat generation limits equivalent to the maximum allowable solid combustible concentration of $3200 \mathrm{~kg} / \mathrm{m}$. Under worst-case conditions (nonchiorinated liquid organics with high heating value at ambient conditions of $38^{\circ} \mathrm{C}$ ), the off-gas system is capable of removing the heat of combustion from a $1 \mathrm{wt} \%$ concentration in the soil. Under cooler ambient conditions, or where the organics in the soil have a lower heating value, such as chlorinated liquid organics or solid organics, soil with higher concentrations of organics could be vitrified.

This liquid combustible limit for the reference off-gas hood is based on extreme estimates of organic liquid contents at a liquid drain site at the Hanford Site (Zimmer 1973). The existing large-scale off-gas hood, however, is designed under less stringent conditions. It will accommodate combustion that occurs from organic liquids in consolidated soil only if the concentration is less than $2300 \mathrm{~kg} / \mathrm{m} / \mathrm{setting}$ or $3 \mathrm{wt} \%$. 
Combustible liquid contents inside sealed containers may not exceed $50 \mathrm{~kg}$ unless the sealed containers are ruptured prior to vitrification or until additional data are collected on how sealed containers that contain combustible Tiquids behave during vitrification. This limit is based on pilotscale empirical data.

\section{Maximum Heat Limit}

Maximum heat from combustion under maximum conditions (3000 kW) is determined from standard heats of combustion of the pyrolyzed gases. Maximum combustible conditions result in a hood-skin temperature of $930^{\circ} \mathrm{C}$ and an entrance temperature into the off-gas system of $750^{\circ} \mathrm{C}$. The existing hood, which is based on maximum combustible conditions expected at a contaminated soil site at Hanford as opposed to a buried waste site, can withstand maximum continuous temperatures of $550^{\circ} \mathrm{C}$ and heatup rates of $50^{\circ} \mathrm{C} / \mathrm{min}$ without compromising its ability to maintain the design vacuum (Buelt and Carter 1986).

High organic content creates high heat loading to the off-gas hood and treatment system. Vitrification of $15 \mathrm{wt} \%$ organic materials would require the off-gas line to withstand $700^{\circ} \mathrm{C}$ temperatures and result in a $700^{\circ} \mathrm{C}$ plenum temperature within the hood.

Maximum Single Combustible Volume $\left(0.9 \mathrm{~m}^{3}\right)$

The maximum volume of gas generation is calculated to be $98 \mathrm{~m}^{3}$ using a logarithmic release equation. A $98 \mathrm{~m}^{3}$ gas generation correlates to a solid combustible volume of $0.48 \mathrm{~m}^{3}$. Eliminating the design factor of two increases the design capacity of the system to a solid combustibles volume of approximately $0.9 \mathrm{~m}^{3}$ while maintaining $20 \%$ excess combustion air (Buelt and Carter 1986). The maximum single combustible volume $\left(0.9 \mathrm{~m}^{3}\right)$ is based on release rate observations from pijot-scale tests. Single solid combustible volumes in sealed containers may not exceed $0.21 \mathrm{~m}^{3}$ at a density of $240 \mathrm{~kg}$ combustibles per $\mathrm{m}^{3}$. This is $50 \mathrm{~kg}$ in a 55 -gal drum.

Maximum Single-Void Volume of a Container $\left(4.3 \mathrm{~m}^{3}\right)$

Maximum single-void volume from a container such as a burial box or empty barrel was determined based on the pilot-and engineering-scale observations that noncombustible gases inside the void are released uniformiy over 
a $5-\sec$ period. The maximum allowable release rate was calculated to be $52 \mathrm{~m}^{3} / \mathrm{min}$ (see above). A simple calculation of a 1 inear release over $5 \mathrm{sec}$ reveals that a maximum void volume of $4.3 \mathrm{~m}^{3}$ can be accommodated in the soil without jeopardizing the ability of the process to contain and treat gaseous effiuents and to maintain a design factor of two $\left(104 \mathrm{~m}^{3} / \mathrm{min}\right.$ ) (Buelt and Carter 1986).

\section{SUMMARY OF TEST RESULTS}

One engineering- and two pilot-scale tests related to combustibies are summarized in this section.

\section{ESLT-11 (Engineering Scale - 1981)}

Combustible gas release is sporadic and may occur in a very short time period. During the ESLT-11 experiment, $0.2 \mathrm{~kg}$ of simulated combustible waste was placed inside a metal canister. Active surface combustion of the pyrolyzed gases occurred over an 18-min period during the 12 -h test. Thus, the release period was onty $2.5 \%$ of the total ISV time (Oma et al. 1983).

\section{PSFT-3 (PiTot ScaTe - 1982)}

A $208-\mathrm{L}$ (55-gal) metal drum containing $38.4 \mathrm{~kg}$ of simulated combustible waste (paper, plastics, rubbers, etc.) mixed with soil was buried between electrodes. When the molten soil first contacted the waste drum, rapid venting of pyrolyzed gases and carbonaceous particulate occurred for about $30 \mathrm{~min}$. The off-gas particle loading, which was high during this period, reached $3600 \mathrm{mg} / \mathrm{m}^{3}$. Slower ventings that lasted for 15 to 30 min each occurred at two other times later in the test. The ISV process was operated for $38 \mathrm{~h}$; however, most pyrolysis gas venting took place over a period of about $1 \mathrm{~h}(2.6 \%$ of the total ISV time) (Oma et a). 1983).

The particulate overloaded the two scrub recycle filters causing failure of the cycionic scrubber and venturi ejector. With the scrubbers inoperable, off-gas temperatures increased and tars and other organic particulate began to collect in the off-gas system, resulting in failure of the exhaust blower. The loss of the hood exhaust forced a shutdown of the power. 
PSFT-4 (Pilot Scale - 1982)

Three 5-gal metal canisters of simulated radioactive combustible waste were buried at approximately the 2-, 3.5-, and 4-ft levels. A 5-gal canister of organic solvent-contaminated soil was buried in the same trench (4B) at the 1-ft leve1, and a 55-gal metal drum with simulated Pu-contaminated soil was buried in an adjacent trench (4A).

Rapid venting occurred at times that coincided with initial contact of the canisters at the $2-\mathrm{ft}$ and $3.5-\mathrm{ft}$ levels. The lack of rapid venting at the 4-ft level may indicate most of the combustibles in the canister at that level were also decomposed and vented during the large gas release that occurred near the $3.5-\mathrm{ft}$ level.

Hood plenum temperature exceeded $600^{\circ} \mathrm{C}$ for an extremely brief period when the drum was first breached in $4 \mathrm{~A}$ and when each combustibles can was breached in 4B. During periods of nominal operation, off-gas temperature peaks never exceeded $550^{\circ} \mathrm{C}$, and plenum temperatures were $<200^{\circ} \mathrm{C}$.

Off-gas loadings in test $4 B$ increased to approximately $300 \mathrm{mg} / \mathrm{m}^{3}$ during vitrification of the can with soil and volatile organics, and increased as high as $1400 \mathrm{mg} / \mathrm{m}^{3}$ during the combustible release periods of the three combustibie waste cans. The sample port became plugged during the third and largest combustible release.

The off-gas scrubbing system, which failed due to a similar gas release during PSFT-3, continued to operate effectively due to system improvements made prior to the experiment. The rapid gas generation from pyrolysis of combustible wastes is believed to be associated with melting of relatively high integrity waste containers. Rapid gas generation is not expected when the wastes are in degraded or low-integrity containers, such as cardboard boxes, and are better mixed with the soil, as is the case with many of the early burial grounds. 
$+$ 


\section{SEALED CONTAINERS}

Gas may be released rapidly from a sealed container in soil that is being vitrified. Containers, especially if they hold combustibles, can build up pressure as the temperature increases. When the container is breached, gases escape to the hood over a very short time period (approximately $2 \mathrm{sec}$ ).

\section{MAXIMUM GAS RELEASE RATE FOR VARIOUS GEOMETRIES OF SEALED CONTAINERS} (Oma et a). 1983)

Theoretical gas releases were calculated for various geometries of sealed metal containers to determine the maximum gas release rate after the fused zone has been breached. Table 1 shows a greater calculated release rate with a 19-L (5-gal) bucket or a $34-\mathrm{L}(10-\mathrm{gal})$ bucket $\left(64 \mathrm{~m}^{3} / \mathrm{min}\right)$ than with a 208-L (55-gal) drum $\left(35 \mathrm{~m}^{3} / \mathrm{min}\right)$. This is because greater pressure is required to breach the fused zone over the narrower gap between the metal sides of a 19-L bucket, resulting in a higher burst pressure and a greater gas release rate.

Sealed containers that do not contain gas-generating combustibles can release pressurized gases when breached (PSCT-I).

Containers of material with a high moisture content can also release water vapor rapidily. The $220^{\circ} \mathrm{C}$ isotherm, which precedes the vitreous zone by approximately $25 \mathrm{~cm}$, can vaporize water at $25 \mathrm{~atm}$ pressure. The water vapor, even in a nonmetallic container, can create a gas release comparable to that from a sealed metal container.

IABLE 1. Calculated Release Rates from Sealed Metal Containers (Oma et a1. 1983)

\begin{tabular}{|c|c|c|c|}
\hline Container & Dia, m & $\begin{array}{c}\text { Burst } \\
\text { Pressure } \\
\text { atm } \\
\end{array}$ & $\begin{array}{l}\text { Max. Gas } \\
\text { Release Rate, } \\
\text { std } \mathrm{m}^{3} / \mathrm{min} \\
\end{array}$ \\
\hline 19-L ( 5-gal) bucket & 0.27 & 25 & 64 \\
\hline 34-L (10-gal) bucket & 0.27 & 25 & 64 \\
\hline 208-L (55-gal) drum & 0.56 & 6 & 35 \\
\hline
\end{tabular}


The maximum postulated gas release is well within the capacity of the large-scale off-gas system (104 $\left.\mathrm{m}^{3}\right)$. Therefore, as long as the criteria for combustible packages $\left(0.9 \mathrm{~m}^{3}\right)$ and void volumes $\left(4.3 \mathrm{~m}^{3}\right)$ inside the sealed containers are met, the ISV process is designed to accommodate such releases. Even though sealed containers limit the applicability of the pilot-scale offgas system, their presence does not hamper the operation of the large-scale system. Actual test data indicate that during ISV pressure containers wil1 fail at pressures far below their atmospheric burst pressure (ESLT-20, ESLT-21, PSCT-4). The fact that actual burst pressures are much less than calculated for large-scale design adds to the conservatism and safety factor of the Targe-scale system when vitrifying through sealed containers (Buelt et al. 1987).

\section{SUMMARY OF TEST RESULTS}

Three engineering- and two pilot-scale tests conducted with seaied containers are summarized here. In these tests, a variety of container types and geometries have been used to evaluate burst pressures, and a variety of substances have been placed in the containers to provide gas-release data for evaluating hood temperature limits and off-gas treatment performance. Further tests with larger containers of combustible organics are needed.

\section{PSCT-1 (Pilot Scale)}

A $19-\mathrm{L}$ (5-gal) metal bucket containing $60 \mathrm{~kg}$ of chemicals in nitrate form was vitrified. A rapid (2- to 5-second) release of gases exceeding hood vacuum was observed on three occasions (Oma et al. 1983).

\section{ESLT-20 (Engineering Scale)}

An aerosol can that was pressurized to over 300 psi without failing in air, failed at 7.6 psi during ISV (Buelt et al. 1987).

\section{ESLT-21 (Engineering Scale)}

An aerosol can filled with $50 \mathrm{~mL}$ of water reached a peak pressure of only 24.5 psi before failing during ISV (Buelt et a1. 1987). 
PSCT-4 (Pilot Scale)

A 5-cm-dia (2-in.-dia) by 30-cm-long (1-ft-long) Schedule 10 pipe with plates welded to the ends was vitrified to investigate the depressurization characteristics of a high integrity container. The container had $17 \mathrm{~mL}$ of trichloroethylene as a simulated hazardous waste gas generator. Depressurization of the container was anticlimactic, occurring over about a 10-min period. The depressurization half-life during this test was higher than expected at about 2 min (Buelt et al. 1987).

Experiment with Sealed Metal Containers of Hazardous Waste (Engineering Scale - 1987)

In an engineering-scale ISV experiment, four simulated waste mixtures were placed in sealed 1-L metal containers, buried at incremental depths, and vitrified (Koegler 1987). Each container was separated by $10 \mathrm{~cm}$ of soil to allow for differentiation among the simulated wastes in the off-gas sampling.

The heatup of the can, breaching of the can by the molten glass, and volatilization of the can's contents were monitored by two thermocouples placed in the can and by the pressure in the can. The can contents release data for each of the four containers are given in Table 2. The rate at which the waste container released its contents is important to the design of largescale experiments. If the release rate is too high, combustion of the container contents may raise the hood temperature above design limits or exceed the off-gas treatment equipment capacity.

\section{TABLE 2. Can Contents Release Data (Koegler 1987)}

\begin{tabular}{|c|c|c|c|c|c|c|}
\hline Can & Contents & $\begin{array}{l}\text { Liquid } \\
\text { Volume } \\
\text { (mL) }\end{array}$ & $\begin{array}{c}\text { Heat of } \\
\text { Combustion } \\
(k c a l) \\
\end{array}$ & $\begin{array}{l}\text { Release } \\
\text { Time } \\
\text { (min) } \\
\end{array}$ & $\begin{array}{c}\text { Liquid } \\
\text { Rate } \\
\text { (ml/min) }\end{array}$ & $\begin{array}{c}\text { Vapor } \\
\text { Rate } \\
\text { (std L/m) }\end{array}$ \\
\hline 1 & photographic chemicals & 750 & 0 & $>13$ & -. & -- \\
\hline 2 & pilot plant chemicals & 750 & 0 & 43 & 17 & 21 \\
\hline 3 & antifreeze & 325 & 815 & 86 & 4 & 3.1 \\
\hline 4 & painting chemicals & 125 & 1638 & 38 & 3 & 0.8 \\
\hline
\end{tabular}


The pressure dropped from off scale, greater than 17 psig or $120 \mathrm{kito}$ Pascals gage ( $\mathrm{kPag}$ ), to zero in less than $2 \mathrm{sec}$ when each can depressurized. The pressure in can 1 stayed at $0 \mathrm{kPag}$ the entire time, suggesting that the can may have leaked and released its volatile contents slowly before being breached by the molten glass. The pressure curves for cans 2 and 3 showed a momentary pressure decrease followed by a pressure increase just before the pressure went to zero, indicating that the can was temporarily resealed by molten glass after its initial loss of integrity.

Calculations indicate that a 40-min release of a 55-gal drum of antifreeze solution (50\% ethylene glycol) in the large-scale system would increase the hood temperature to about $290^{\circ} \mathrm{C}$. Four drums processed simultaneously at an off-gas flow of $100 \mathrm{~m}^{3} / \mathrm{min}$ would raise the hood temperature to $765^{\circ} \mathrm{C}$ (Koegler 1987), slightly above the $750^{\circ} \mathrm{C}$ criterion for the off-gas system.

The waste in can 4 was $98 \%$ methylethyl ketone (MEK). Calculations indicate that the destruction of a 55-gal drum of MEK over a period of $40 \mathrm{~min}$ would increase the large-scale ISV off-gas hood temperature to about $550^{\circ} \mathrm{C}$. Two drums destroyed simultaneously would raise the hood temperature to about $930^{\circ} \mathrm{C}$, well over the hood design specification (Koegler 1987). Thus, one 55-gal drum of MEK or three 55-gal drums of ethylene glycoi could be destroyed in $40 \mathrm{~min}$ (only if the processing rate is uniform--perhaps an unlikely assumption) without exceeding the design criteria for the existing large-scale offgas system.

Items requiring further clarification to verify off-gas system performance with larger containers of combustible organics include

- the effects of container size on release rate

- the effects of partially filled containers on release rate

- the fraction of combustion heat lost through the hood walls. 


\section{RADIANT HEAT SURGE}

Based upon test data analysis performed in 1990, an additional phenomenon that causes off-gas hood pressurization has been hypothesized. This "Radiant Heat Surge" hypothesis was evolved after anaiysis of hood pressurizations indicated that escaping gases and ideal gas law volume expansions were clearly insufficient to explain some of the incidents. A qualitative expranation of this hypothesis is as follows.

During normal ISV processing a "cold cap" of (barely) solidified glass forms on the surface of the melt due to the heat loss from the surface of the melt. This "cold cap," which is a black color, is disturbed when large gas volumes are evolved from the melt front. The "cold cap" has been observed to rapidly melt as bright red molten glass is circulated by gases rising up through the melt. This rapid change from a dark, cool "cold cap" to a red hot melt surface increases the radiant heat flux into the off-gas hood in a matter of seconds. If the gas evolution is accompanied by particulates, either from sand of a particular size fraction or combustion particulates (smoke), that obscure the hood interior, the radiant heat flux could be captured and deposited into the off-gas hood atmosphere. This rapid temperature increase might result in gas volume expansion which, when combined with the gas volume brought into the hood through the meit, would overload the blower system (since it was not designed for this combination). An overload beyond the blower capacity could result in a hood pressurization and venting to relieve the excess gas volume. This hypothesis is compatible with the few hood pressurizations that have been observed to date.

This "Radiant Heat Surge" hypothesis will be more quantitatively analyzed in the future. 


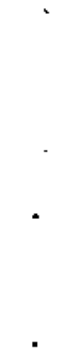




\section{ELECTRICAL SHOCK}

Potential electrical shock hazards associated with the ISV process have been evaluated. These potential hazards include the electrode busses extending through the top of the off-gas hood and generation of voltages or currents to facilities or underground service lines outside the melt zone. Discussions of these hazards are summarized here.

An additional potential electrical hazard that needs to be assessed is conductive inclusions that extend outside the safety zone. Engineering- and pilot-scale tests have been conducted with buried metal, but they have addressed processing considerations rather than safety considerations.

\section{ELECTRODE BUS HAZARD}

In 1987 electrical shock was evaluated as a potential hazard associated with a large-scale test of ISV in the safety analysis for the 216-2-12 crib test at Hanford. The electrode busses extend through the top of the off-gas hood for electrical connection to the electrodes. During some periods of operation, these busses will have a potential of up to $4200 \mathrm{~V}$. Because busses have exposed portions that are susceptible to accidental contact, extreme caution must be exercised; safety procedures outlined in the equipment's safe operating procedures must be followed when inside the safety zone.

\section{STRAY VOLTAGE HAZARD}

Stray voltage hazard was evaluated in 1986. Voltages up to $4160 \mathrm{~V}$ and currents up to $4000 \mathrm{~A}$ are used in the ISV process. The potential for generating stray voltages or currents to nearby facilities or underground service lines is very smali, however, because 1) the process employs an isolated electrical power supply; 2) the system's characteristics make it a poor transmitter of induced voltages; and 3) numerous electrical safety precautions are observed while testing and operating the ISV system.

In an isolated power supply system, an electrical hazard occurs onty if someone or something completes the electrical path between a pair of electrodes. Although electrodes are initially in contact with moist soil, no 
current conduction among electrodes has been detected in large- and pilotscale tests, indicating that the electrodes are poor grounding rods. In addition, no potential exists on nearby underground metallic service 1 ines unless they shorten the electrical path between electrodes, which are generally only $15 \mathrm{ft}$ apart. A further impedance to stray voltages is the l-ft-thick, nonconductive, dry soil zone that forms a natural insulative boundary around the vitreous zone and, eventually, the electrodes.

The absence of windings in the ISV equipment and the low permeability of the surrounding soil make ISV system a poor transmitter of electromagneticinduced voltages. The highest voltage gradient measured at the perimeter of the hood in pilot-scale tests has been $9.6 \mathrm{~V} / \mathrm{f}$, which rapidly dropped off to $0.32 \mathrm{~V} / \mathrm{f}$ at a location 5 to $10 \mathrm{ft}$ away.

Electrical safety precautions observed while testing and operating the ISV system further limit the potential for stray voltages. These precautions include the following:

- The hood is grounded.

- High-potential protective gloves and shoe covers are required for personnel entering the safety zone.

- Minimum distances from the contaminated zone are specified for underground service 1 ines. 


\section{RISK ANALYSIS}

Risk/safety analyses have been conducted for reference sites. These assessments include accident analyses, equipment failure analyses, and general safety evaluations. Even the worst-case scenario in these assessments results in only minor consequences for the ISV worker and negligible consequences to the public. Because of differences among sites, however, it is prudent that a site-specific assessment be completed for future demonstrations.

\section{CALCULATED EXPOSURES AT A REFERENCE SITE (Oma et al. 1983)}

To analyze the occupational and public safety of routine and nonroutine ISV operations for both the near and far term, a Hanford waste site (the 216-Z-1A tile field in the 200 Area) was selected as a reference. Radionuclide release rates from the soil during vitrification were estimated, and the 216-Z-1A waste inventory reported by Owens (1981) was the basis for the radionuclide source term.

\section{Exposures During Routine Operation}

Tables 3 and 4 give the radiation doses from routine operations in the near term for both the ISV worker and the public, respectively. For all routine exposures, radiation doses are estimated to be well below federal guideTines set by DOE. Of all activities associated with ISV operations, the maximum occupational dose is expected to occur while the worker is placing electrodes. The low exposure levels can be seen in Table 3, where the occupational dose for this activity is compared to the dose that would be received during the same time period from natural background. The maximum exposed worker would receive a dose roughly the same as background radiation. The doses calculated for ISV operation at this reference site are substantially below the DOE regulations on exposure for routine operations to both workers and the generat public (US DOE 1981).

\section{Accident Scenarios and Worst-Case Exposures}

Abnormal exposures for both the ISV worker and the public from the vitrification process were calculated using worst-case scenarios. Four 
TABLE 3. Whole Body Radiation Doses from Routine Operations (Oma et a7. 1983)

\author{
Occupational Dose (Electrode Emplacement) \\ All workers: $\quad 0.09$ man-rem \\ Maximum exposed worker: 0.01 man-rem \\ Natural Background \\ Exposure rate: $\quad 7 \mu \mathrm{R} / \mathrm{h}$ \\ Total $(1880 \mathrm{~h}): \quad 0.01 \mathrm{rem}$
}

TABLE 4. Public Dose Commitments from Routine Operations

(Oma et al. 1983)

\begin{tabular}{lccc} 
& $\begin{array}{c}\text { Max. Exposed } \\
\text { Indiv.. rem. }\end{array}$ & $\begin{array}{c}\text { Population, } \\
\text { man-rem }\end{array}$ \\
\cline { 2 - 2 } 1st yr dose (lungs) & $3 \times 10^{-8}$ & $9 \times 10^{-3}$ \\
$50 \mathrm{yr}$ dose (bone) & $1 \times 10^{-5}$ & $5 \times 10^{-1}$
\end{tabular}

accident scenarios identified as having the potential to occur at the representative site are as follows:

- Uncontrolled venting from a subsurface structure. The run is proceeding normally when localized venting of gas from the surface of the waste site outside the hood is noticed. The phenomenon, which is investigated by a radiation monitor, is short-lived, and the run continues unabated. It is later determined that the venting was due to limited volatilization and pressurization of waste liquid remaining in a $6-m-7$ ong section of the stainless steel distribution pipe.

- Break in 1 ine between hood and off-gas system. The run is proceeding normally, with no cold cap. The effluent line between hood and off-gas system breaks, releasing the gaseous effluents directiy to the atmosphere. Power to the electrodes is cut off immediately. As a cold cap forms over the melt area, the effluents released to the atmosphere decrease exponentially with a half-hour half-time. Gaseous effluents are released to the atmosphere for a 4 -h period before a sufficient cold cap is formed to prevent further discharge.

- Collection tank leak. The run is progressing in a normal manner with only $20 \mathrm{~h}$ remaining until the run is to be completed. A leak develops in the bottom of one quencher-scrubber collection tank, which allows the entire contents of the tank to spill into the pan that lines the floor of the hood. The decision is made to complete the run without one of the scrubbers. Ten half-hour sampling periods are spent in the off-gas 
van, resulting in an additional dose to the worker. No radionuclides are released to the atmosphere, so this accident does not affect the public.

- Gaseous effluent release to the off-gas vans. The run is progressing in a normat manner when a leak develops in the off-gas system after the off gas clears the blower and is inside the van. Because the off gas is very humid and could damage the equipment, the run is terminated at this point. Therefore, the workers spend only one half-hour sampling period in the contaminated atmosphere. This accident would not increase the exposure of the offsite population above that received from normal operations.

Three additional scenarios are also identified as being possible at other sites, but not at the representative site:

- Accidental excavation of the waste while removing overburden. As the overburden is removed using large earth-moving equipment, it is checked by radiation monitors. It is assumed that, due to inaccurate survey or operator error, a section of contaminated soil is uncovered. The error is discovered immediately by the monitor, and the area is covered with clean soil. The area that was uncovered is assumed to be the width of the contaminated zone, about $6 \mathrm{~m} \times 2 \mathrm{~m}$. The amount of contaminated dust suspended from clearing and covering this area is $2 \mathrm{~kg}$, released over a period of 10 min.

- Criticality of fissionable materials. The peak sgil concentration of ${ }^{239} \mathrm{Pu}$ in the reference site is $4 \times 10^{4} \mathrm{nCi} / \mathrm{g} 239 \mathrm{Pu}$ and $240 \mathrm{Pu}$ in a limited area around the distributor pipe (Kennedy et a1. 1982). This level of contamination reaches a depth of $1 \mathrm{~m}$ below the pipe. Using an activity fraction of $80 \%{ }^{23} \mathrm{Pu}$, this would be about $5 \times 10^{-4} \mathrm{~g} 239 \mathrm{Pu} / \mathrm{g}$ soil. Thus, the areal concentration would be $0.9 \mathrm{~kg} / \mathrm{m}^{2} 239 \mathrm{Pu}$. This is below the acceptable areal concentration for wet soji, and well below the critical concentration (see section on Plutonium Criticality). Because the reference site contains a greater contamination level than other typical contaminated soil sites, criticality is not of great concern for these types of sites.

- Waste-induced explosion. If contained organic matter is encountered during ISV, it will generally pyrolyze and combust when the gases reach the soil surface. The only time that this might not occur is during vitrification of sites containing highty reactive or potentially explosive materials. The off-gas system is designed to contain large transient pressure surges, but a large enough explosion could cause venting around the hood, or even disrupt the hood and off-gas lines. This would result in a release mechanism similar to that described above for an off-gas line leak. Releases and doses could be as much as an order of magnitude greater than from a simple line break. 
No explosive materials are believed to be present in the 216-Z-1A site, or in most of the other TRU-contaminated soil sites. However, the concentration and configuration of combustible materials and their potential for explosion would be evaluated for each site before vitrification would be attempted.

The most serious abnormat condition is a break in the off-gas line. For the specific exposures calculated, see Tables 5 and 6 . None of the public doses from potential accidents investigated for ISV application at site 216-Z-1A falls within the $>5$ rem dose for the total body that must be reported within $72 \mathrm{~h}$.

\section{Far-Term Exposures}

Far-term exposures were calculated for transients, inadvertent intruders, intentional intruders, and permanent residents in the vicinity of the waste site. Doses were calculated for these categories for individuals 1000 and 10,000 years in the future using three scenarios: doses resulting from a site that is 1) left in its present state, 2) covered with an engineered barrier, and 3) selectively vitrifjed in the highly contaminated areas and covered with an engineered barrier. Pathways of concern were determined and evaluated using the allowable residual contamination level techniques described by Napier (1982). The pathways are direct irradiation; inhalation of resuspended material; and ingestion of contaminated crops, groundwater, and animal products.

TABLE 5. Occupational Doses from Accidental Releases

(Oma et a1. 1983)

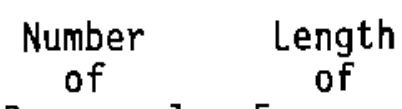

Personnel

Accident

Uncontrolled venting

Break in off-gas

line

Excess overburden remova]
1

15 min

$2 \quad 10 \min$ 1st year Dose Commitment to Each Worker, rem

Total Body Bone Lung

$1 \times 10^{-3}$

$2 \times 10^{-2}$

$2 \times 10^{0}$

$6 \times 10^{-3}$

$1 \times 10^{-1}$

$1 \times 10^{1}$

$3 \times 10^{-3}$

$4 \times 10^{-2}$

$5 \times 10^{0}$ 
IABLE 6. Public Dose Commitments from Postulated Abnormal Occurrences (Oma et al. 1983)

Uncontrolled Venting

$$
\text { lst year (lungs) }
$$

50 year (bone)

Off-Gas Line Break

lst year (lungs)

50 year (bone)

Excessive Overburden Removal

1st year (1ungs)

50 year (bone)

\section{Maximum Exposed Individual, rem Population, man-rem}

$5 \times 10^{-5}$

$5 \times 10^{-4}$

$3 \times 10^{-2}$

$3 \times 10^{-1}$

$1 \times 10^{-2}$

$9 \times 10^{-2}$
$2 \times 10^{-1}$

$2 \times 10^{0}$

$1 \times 10^{2}$

$1 \times 10^{3}$

For permanent residents, gardening and eating of the garden produce could cause an exposure of $10 \mathrm{rem} / \mathrm{yr}$ from the unaltered site for both the 1000 and 10,000 year scenarios. With an engineered barrier and selective vitrification, the dose would be reduced to $1 \times 10^{-2} \mathrm{rem} / \mathrm{yr}$.

The scenarios that best distinguish the capabilities of the vitrified sites from unaltered sites and barrier sites involve intentional and unintentional human intrusion (Table 7). Reduction in radiation dose from 1 to as much as 5 orders of magnitude may be achieved over no-action or surface barrier application.

\section{SAFETY ANALYSIS FOR CONCEPTUAL DESIGN}

\section{Example Site}

The example site selected for this Safety Assessment is assumed to be a tile field with a waste volume of $5.2 \times 10^{6} \mathrm{~L}$ containing $57.4 \mathrm{~kg} \mathrm{Pu}$ and $1 \mathrm{~kg}$ Am. Chemical wastes are aiso considered to occur, consisting mainiy of $\mathrm{CCl}_{4}$ and TBP. 
TABLE 7. Public Dose Commitments for Far-Term Intrusion, rem (Oma et a1. 1983)

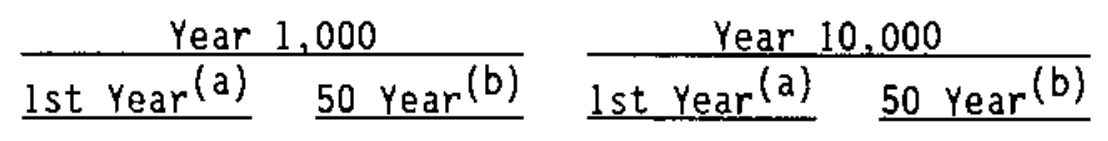

Drilling

Vitrified site

6

15

3

8

Excavation

Vitrified site

0.006

0.02

0.003

0.008

Vitrified Curio (c)

0.2

10

0.1

5
(a) Lung dose.
(b) Bone dose.
(c) Total body dose.

Accident Analysis

None of the doses from potential accidents described by 0ma et al. (1983) fall into DOE reportable categories. Rockwell Hanford Operations Manual RH0-MA-220, however, states that the annual limit is 7.5 rem, which is exceeded by the off-gas line break scenario. For this reason, the conceptual design has been modified to include a dual off-gas 1 ine between the hood and off-gas trailer that can be automatically activated within $1 \mathrm{sec}$ of off-gas line failure. This will reduce exposure from $5 \mathrm{~min}$ to $\mathrm{l} \mathrm{sec}$, resulting in a first-year dose commitment to the lung of $0.03 \mathrm{rem}$, well within the criteria set by RHO-MA-220.

\section{Equipment Failure Analysis}

An equipment failure analysis was performed to provide a data base for determining the $Q A$ levels of the process equipment. The analysis postulates plausible off-standard conditions, events causing such a condition, engineered safeguards, consequences, and the 168-h average and instantaneous air concentrations of radionuclides at the point of release. The equipment failures examined include the following:

- wet HEPA filters

- scrub pump failure 
- blower failure

- off-gas power failure with diesel generator backup

- condenser/heat exchanger glycol cooling system failure

- no water to quencher

- no water to scrubber

- gas cooler glycol system failure

- air compressor faiture

- gas cooler plugged

- quencher floods

- leak of glycol in air cooler

- scrub solution pipeline or pump leak

- scrub tank leaks

- off-gas line failure

- hood failure

- valve sticks in closed position.

The highest release concentrations occur with failure of the glycol cooling system for the heat exchanger and condenser. A dual off-gas line was included in the conceptual design to mitigate the consequences of such an unlikely event. This shifted the most severe consequences to a loss of the cooling system. The $168-h$ average and instantaneous concentrations for cooling system failure are well within the immediate response limits.

Since the worst-case event does not pose a significant hazard to the public (Oma et al. 1983), and since the single equipment failure analysis shows that no single event exceeds both the inmediate response and unusual occurrence limits, it was recommended that the overall system be established at QA level II. 


\section{SAFETY ANALYSIS FOR LARGE-SCALE VITRIFICATION AT A SPECIFIC SITE}

This safety analysis for the 216-2-12 Crib at Hanford evaluated potential hazards associated with the operation. It identified the inventory of chemicals and radionuclides as the primary potential hazard. Six accident scenarios were examined that could result in higher than expected exposure of onsite and offsite personnel to the potentially hazardous chemicals and radionuclides.

Potential Hazards

The following potential hazards were examined:

- Electrical Shock - (discussed above)

- Nuclear Criticality - (discussed above)

- Mass, Gravity, and Height - use of crane

- Pressure - Instrument air is used to actuate control elements (valves) and the scrub solution in lines leading to the scrubber and quencher. In the event of a complete failure of all off-gas systems, a slight over-pressure of the hood would occur. The hood pressure would be only slightly above atmospheric pressure. Because fluid pressures during operation of the test are not excessive and proper standards were followed during construction, the potential for injury from this energy source is minimal.

- Pumps, Blowers, and Motors - inaccessible to personnel or in areas not usually frequented during operation. Pumps and motors are shieided; blowers are in an envelope within the off-gas trailer.

- Kinetic - Linear - use of cranes with loads in motion

- Corrosion - Caustic will be used, if necessary, to neutralize any acid formed in the scrub solution by the scrubbing of $\mathrm{SO}_{\mathrm{x}}$ from the off gas. Staff training and the use of necessary protective clothing and eye protection when working with or around the $\mathrm{NaOH}$ will satisfactorily prevent or mitigate the hazards involved.

- Explosion-Pyrophoric Materials - The small amounts of nitrates present in the site do not pose an explosion hazard. Repeated tests of the ISV technology have shown that nitrates in the soil are effectively broken down into elemental $\mathrm{N}_{2}$ and $\mathrm{O}_{2}$ in the extreme environment produced by the vitrification process.

- Heat - The off-gas hood and the lines entering the off-gas trailer will be thermally hot during operation and part of the cool-down phase. The 
possibility of sustaining a burn from accidentally touching the hot external surfaces exists. Care must be taken and appropriate safety equipment (gloves, long sleeve shirts or lab coats) must be used when contacting or working close to these surfaces.

Because there is little or no combustible material in the 216-Z-12 crib, the temperature of the off gas is not expected to exceed approximately $100^{\circ} \mathrm{C}\left(212^{\circ} \mathrm{F}\right)$. The external temperature of the hood will be approximately the same temperature as the off gas.

- Flammable Material - Flammable material will not be stored within the safety zone during the test operation. Both $A B C$ and Halon fire extinguishers will be available at the site in the event of a fire. (Combustibles within the soil site are discussed in a previous section.)

- Thermal Radiation - Although the in situ vitrification process involves melting soil at the waste site, personnel are protected from the inherent thermal radiation. This protection results from an insulating nonflammable blanket and the off-gas hood that is located over the melt zone.

- Electromagnetic and Particulate Radiation - Radiation sources associated with the vitrification process pose the highest potential hazard to both onsite and offsite personnel. Potential exposure to ionizing radiation and to radioactive material can result from severa] routes. The first route is external exposure to ionizing radiation from the waste form itself or from the scrub liquid. This route would result in exposure to ISV personnel only. Another route of radiation exposure would be the release of radionuclides into the air via the off gas. The air route has the potential for exposing people other than just the ISV personnel.

Many safeguards were designed into or are inherent to the ISV process to prevent or mitigate potential airborne releases. Every critical component in the off-gas system has a backup power generation system, parallel banks of primary HEPA filters and a back-up secondary HEPA bank, and a backup blower to maintain a vacuum in the hood. All of these backup systems are automatically activated, if necessary, by the process control system. Fail-to-open valves, alarms, and radionuclide sensors are all safety precautions.

Tests have shown that $99 \%$ to $99.99 \%$ of the radionuclides within the melt zone are retained by the molten soil. And under normal operating conditions, greater than $99.99 \%$ of the radionuclides released from the melt zone are retained by the off-gas treatment system. Nevertheless, several different scenarios could potentially lead to the radiation exposure of people from this hazards source. Therefore, this hazards source is analyzed further in the accident analysis.

- Toxic/Pathogenic Hazard - The same safeguards preventing or mitigating the release of radionuclides into the environment are applicable to chemicals, including sensors to detect the presence of $\mathrm{NO}_{x}$ and $\mathrm{SO}_{x}$. 


\section{Accident Scenarios}

Six "breach of containment" accident scenarios were identified that could lead to a release of or exposure to the chemical or radionuclide inventory. Mitigating features that apply to all but the last scenario include detectors and alarms for radiation, $\mathrm{SO}_{x}$, and $\mathrm{NO}_{x}$, and the ability to cease power supply to the electrodes, thus decreasing releases from the melt zone.

Exposure to the radionuclide source term was determined for four different groups: 1) the ISV staff, 2) the non-ISV onsite staff, 3) the offsite maximally exposed individual, and 4) the general offsite population. For each group, 1-yr and 50-yr dose commitments were determined.

A fault-tree analysis was performed to determine the circumstances (e.g., equipment failure) that could lead to an occurrence. Probabilities for the occurrence of each incident were calculated using standard accident probability sources (Vesely et a1. 1981; AEC 1974; Swain and Guttmann 1983). The scenarios and respective probabitities are as follows:

1. Loss of hood vacuum and failure of blower on combustion air inlet line. $\mathrm{P}=9 \times 10^{-5}$

2. Loss of hood vacuum. $P=1 \times 10^{-3}$

3. Scrubber system fails to operate. $P=1 \times 10^{-4}$

4. HEPA filter ruptures. $P=3 \times 10^{-5}$

5. Air duct failure between the blower and the stack within the off-gas trajler. $P=2 \times 10^{-1}$

6. Drilling the pilot hole into the contaminated zone during electrode installation. $P=1 \times 10^{-4}$

\section{Accident Risk Assessment}

Overall decontamination factors, radionuclide releases, and radiological consequences were calculated for all six scenarios. Radiological consequences were highest for Scenario 1. These doses for the critical organ (1ung) 1-yr commitment were 300 mrem for the ISV worker, 50 mrem for the onsite non-ISV worker, and 2 mrem for the maximaliy exposed offsite individual. Worst-case scenario doses for the 50-yr committed critical organ (bone) were 3,000 mrem 
for the ISV worker, 400 mrem for the onsite non-ISV worker, and 10 mrem for the maximally exposed offsite individual. Doses for all the other scenarios were at least two orders of magnitude lower for all three groups evaluated.

Because even the worst-case scenario results in only minor consequences for the ISV worker and negligible consequences to the public, the maximum consequence category possible would be "extremely low." Scenario 2 ( $1.2 \times 10^{-3}$ probability) falls into the "low" probability category, and a] other scenarios fall into the "extremely low" probability category (Jones 1986). Therefore, based on the doses and probabilities, a1] of the accident scenarios would be in the risk category of "extremely low."

\section{Application of Risk Analysis to Vitrification of Other Waste Sites}

In general, the assumptions made for the site-specific risk analyses are still valid for those particular sites. They are probably not directly valid for any new sites where the ISV technology is appitied. Therefore, it is prudent that a site-specific assessment be completed for any site where a demonstration is planned.

The potential impacts of materials that were not included in the 216-Z-12 vitrification site should be assessed. These materials include explosive/pyrophoric materials and volatile flamable materiais (particularly those in sealed containers).

Before an ISV demonstration is performed at another site, a complete reevaluation of the potential contaminant release mechanisms and accident scenarios should be completed. Several differences exist among sites: different waste types and quantities; differences in waste site conditions (e.g., depth of overburden, soil moisture content, etc.); differences in site meteorological conditions; different population distribution surrounding the site; and changes in the actual ISV equipment (e.g., electrode feeding mechanism).

Assuming that either sealed containers, explosive/pyrophoric materials, and/or substantial quantities of combustible material are present in the demonstration site, several additional release scenarios may be possible. 
These include overpressurization of the off-gas hood and release of both gaseous and solid contaminants, and release from the soil outside of the hood. other potential scenarios may be identified during a detailed assessment. 


\section{PLUTONIUM CRITICALITY}

The possibility of a plutonium criticality occurring in the meit or offgas system during in situ vitrification of a Pu-contaminated waste site has been considered since the beginning of the ISV program at PNL. Most of the studies in this area was performed in the early 1980s. Scenarios were developed in which Pu could conceivably be concentrated in amounts large enough to become critical under optimum conditions. Assumptions were made about the behavior of Pu under process conditions, and calculations were performed to obtain general assurance of safe operating limits for minimum critical mass and areal concentration under worst-case conditions. Although experimental work has been limited, and further engineering- and pilot-scale tests are recommended, no credible concentration mechanism has been identified for Pu-239 or other TRU fissionable isotopes.

\section{FISSILE ISOTOPES}

Table 8 contains the estimated (ANSI/ANS-8.15; ANSI/ANS-8.1-1983) moderated and unmoderated spherical subcritical mass 1 imits of nuclides that may need to be considered from the standpoint of criticality safety in ISV. The primary element of interest is plutonium, in particular the isotope ${ }^{239} \mathrm{Pu}$. The values in Table 8 serve as a guide to the relative importance of various nuclides. Most of the estimates are calculated only, with little or no experimental validation.

\section{PLUTONIUM CONCENTRATION MECHANISMS}

For a subcritical Pu waste site to become critical during ISV processing, extensive waste densification or selective Pu migration (as opposed to actinide migration) must occur. Four feasible scenarios capable of causing a criticality are identified below. 
TABLE 8. Estimated Subcritical Mass Limits for Vacjous Fissile and Non-Fissile Nuc] ides [ANSI/ANS-8.15;

ANSI/ANS-8.1-1983(2)]

\begin{tabular}{|c|c|c|c|}
\hline \multirow[b]{2}{*}{${ }^{23} 3 \mathrm{U}$} & \multirow[b]{2}{*}{ Aqueous, $g$} & \multicolumn{2}{|c|}{ Metal, kg } \\
\hline & & $\begin{array}{c}\begin{array}{c}\text { Water } \\
\text { Reflector }\end{array} \\
-\end{array}$ & $\begin{array}{c}\begin{array}{c}\text { Steel } \\
\text { Reflector }\end{array} \\
-\end{array}$ \\
\hline${ }^{235} \mathrm{U}$ & 760 & - & - \\
\hline${ }^{237} \mathrm{~Np}$ & - & 30 & 20 \\
\hline${ }^{238_{\mathrm{Pu}}}$ & - & 4 & 3 \\
\hline${ }^{239} \mathrm{Pu}$ & $450^{(1)}, 480^{(2)}$ & - & - \\
\hline $240_{\mathrm{Pu}}$ & - & 20 & 15 \\
\hline $241_{\mathrm{Pu}}$ & 200 & - & - \\
\hline${ }^{242} \mathrm{Pu}$ & - & 60 & 40 \\
\hline${ }^{24} 1_{\text {Am }}$ & - & 24 & 16 \\
\hline $242 m_{\text {Am }}$ & 13 & - & - \\
\hline${ }^{243} \mathrm{Am}$ & - & 35 & 25 \\
\hline${ }^{243} \mathrm{Cm}$ & 90 & - & - \\
\hline${ }^{244} \mathrm{Cm}$ & - & 5 & 3 \\
\hline${ }^{245} \mathrm{Cm}$ & 30 & - & - \\
\hline${ }^{247} \mathrm{Cm}$ & 900 & - & - \\
\hline${ }^{249} \mathrm{Cf}$ & 10 & - & - \\
\hline${ }^{25} 1_{C f}$ & 5 & - & - \\
\hline
\end{tabular}

\section{Undissolved $\mathrm{PuO}_{2}$ Settling on Melt Bottom}

Plutonium contajned in soils is typically in axide form. One scenario to evaluate is that the solubility limits of $\mathrm{PuO}_{2}$ in ISV glass may prevent complete dissolution of $\mathrm{PuO}_{2}$, leading to undissolved $\mathrm{PuO}_{2}$ concentrating at the melt bottom. 
Plutonium oxide is an extremely stable compound. Plutonium (IV) silicate is also very stable, to the point that if any plutonium oxide reaction occurs during ISV, it will be to incorporate the plutonium into the silicate matrix.

Based on known plutonium solubilities in high-level waste glasses, which are very similar to ISV glass, there should be no solubility limits exceeded during ISV of any TRU waste site. The solubility figure for $\mathrm{PuO}_{2}$ in highlevel waste glass, which should be similar to that of ISV waste glass, is $>5 \%$. Since $\mathrm{PuO}_{2}$ concentration in the most concentrated soil is much less than the $5 \%$ solubility 7 imit, $\mathrm{PuO}_{2}$ solubility in the ISV glass should be high enough to incorporate all the $\mathrm{PuO}_{2}$ in the melt. The average worst-case trench conditions are two to three orders of magnitude below the soiubility limit.

Concentration by settling of undissolved $\mathrm{PuO}_{2}$ during ISV is considered unlikely for two basic reasons. First, the ISV melt advances at a very slow rate, less than $12 \mathrm{~cm} / \mathrm{h}$, and as such, any plutonium oxide will have a long period to dissolve before significant concentration can occur with $\mathrm{PuO}_{2}$ deeper in the waste site.

Second, $\mathrm{PuO}_{2}$ is typically a fine powder, which, even if it remained undissolved, would become thoroughly mixed within the glass by convective currents, diluting any zones of high plutonium concentration. This was verified in PSFT-3 (1982) with waste material spiked with rare earth elements. Simulated waste material was spiked with rare earth elements (Ce, La, and $\mathrm{Nd}$ ), which are expected to behave similarly to Pu. After melting and sampling of the solidified waste block from PSFT-3, it was found that Ce was uniformly distributed laterally throughout the block at a concentration approximately 14 times less than in the initial waste material. Uniform distribution of the rare earths suggests that actinides such as Pu would not migrate if they don't reduce (Oma et a]. 1982).

\section{$\mathrm{PuO}_{2}$ Reduction to Metal Form and Settling on Melt Bottom}

Another Pu concentration scenario is that possible high reduction conditions would cause reduction of $\mathrm{PuO}_{2}$ to $\mathrm{Pu}$ metal, with subsequent settling of 
the metal at the bottom of the melt. Such settling would cause a denser localized volume of $\mathrm{Pu}$, increasing critical propensity.

$\mathrm{PuO}_{2}$ is a very stable oxide. Nearly all other oxides present, including $\mathrm{SiO}_{2}, \mathrm{FeO}_{2}$, and $\mathrm{Al}_{2} \mathrm{O}_{3}$, are more likely, thermodynamically, to be reduced to their elemental forms than $\mathrm{PuO}_{2}$ or $\mathrm{UO}_{2}$. It is highly unlikely that ISV would ever have reducing conditions of that magnitude, or that ISV could proceed if al1 the soil substrate was reduced (0ma et al. 1982). Reduction to this extent would cause failure of the electrode system due to metallic shorting.

Data for the free energy of formation of $\mathrm{PuO}_{2}$ were calculated from data given for $\mathrm{Pu}, \mathrm{O}_{2}$, and $\mathrm{PuO}_{2}$ in Barin and Knocke (1973) and Barin, Knocke, and Kubaschewski (1977). Comparison with data on the free energy of formation of $\mathrm{SiO}_{2}$ (glass) per gram-atom of oxygen (Wicks and Black 1963) indicates that if no solution of Pu metal in $\mathrm{Si}$ or $\mathrm{PuO}_{2}$ occurs, no reduction of $\mathrm{PuO}_{2}$ to metal would occur. Data for the free energy of formation of $\mathrm{Pu}_{2} \mathrm{O}_{3}$ as a function of temperature (Wiege1, Koty, and Scaborg 1986; Flotow and Teltenbaum 1981) indicate that $\mathrm{Pu}_{2} \mathrm{O}_{3}$ is appreciably more difficult to reduce than is $\mathrm{SiO}_{2}$, and that if the oxides or metal did not dissolve in each other or interact, absolutely no $\mathrm{Pu}$ would form until all $\mathrm{SiO}_{2}$ was reduced. Even at $1700^{\circ} \mathrm{C}$, which is near the melting point for $\mathrm{SiO}_{2}$, the Pu content of any $\mathrm{Si}$ metal produced will be much lower than the Pu content of the glass phase.

Thus, the potential for a Pu criticality in the melt is extremely remote provided the $\mathrm{Pu}$ is disposed of in an ionic form. Plutonium disposed of in the metal form is expected to oxidize in the pit unless it was disposed of in large pieces or was somehow protected in a localized anaerobic environment. Still needing to be investigated is the effect of ISV on the kinetics of Pu transforming to an oxidized state.

Schonfeld's (1961) phase diagram of Pu metal in iron indicates that the concentration 1 imit of $\mathrm{Pu}$ in iron is approximately $18 \%$ for high iron concentrations. As a result, there appears to be some potential for Pu metal to be incorporated in the metal slab as the ISV melt progresses downward. This needs to be evaluated further. 


\section{Densification of the Waste During Melting}

Densification of the melt during ISV is another possible criticality mechanism. Extensive densification could result in a criticality if coupled with the complete melting and phase separation of the metal canister, which acts as a neutron absorber, from the rest of the waste. It may be desirable to run a computer code which determines the minimum k-effective allowable for various arrays of 55-ga] drums that may undergo ISV processing.

A study of criticality parameters of 55-gal waste drums (B7yckert and Carter 1980) showed that as a 5-tier array of full-density flattened cores collapses one dimensionally to $25 \%$ of the original volume, there would be a small increase in k-effective. Most of the expected increase will occur only if there is an increase in fissile core density. Fortunately, the dilution effect caused by the melt's $\mathrm{PuO}_{2}$ solubility and convection currents should keep densification from occurring on a very large scale, and the evaporation of soil moisture should further reduce the potential for a critical condition. Criticality Conditions in the Scrub Tanks Ouring ISV Processing

The potential for a criticality in the scrub system needs to be evaluated further.

\section{OTHER CRITICALITY CONCERNS}

Several other criticality concerns besides Pu concentration have been evaluated: 1) pyrolysis, 2) changes in the neutron reflection/absorption properties of the soil, and 3) densification of moderating materials that have higher hydrogen density than water.

\section{Pyrolysis}

Clayton (1979) indicates that criticality could occur in an underground trench simply by driving off water, which happens in the initial stages of ISV. This could occur, however, only in large (effectively infinite) systems where 1) the ratio of absorbing atoms to fissile atoms, rather than the concentration, controls the reaction; 2) the neutron mean free path is 1ong; and 3) the critical mass and areal concentration are much larger than those given 
for moderated soil conditions. If the ISV site meets the mass or areal concentration limits specified, this pyrolysis condition need not cause a problem.

\section{Changes in the Neutron Reflection/Absorption Properties of Soil}

Four material changes occur during ISV that might cause changes in the neutron reflection/absorption properties:

- The soil is densified at least $30 \%$ and becomes glasslike.

- Organics and combustibles are volatilized out of the melt.

- Water is evaporated out of the melt area.

- Any metal in the melt area melts away and settles.

It is estimated that the melting of soil will increase the density by $30 \%$ due to the removal of interstitial voids. The soils act as reflectors for neutrons produced in the waste. Even if no change occurs to the fissionable materials, the increase in reflector density couid increase the total system reactivity.

From a report detailing the criticality parameters of 55 -gal waste drums (Blyckert and Carter 1980), it was determined that only the decreases in water and metal content should affect the critical propensity of the melt. However, complete evaporation of water in the melt area occurs long before the metal begins to melt.

\section{Densification of Polyethylene Moderating Material}

Calculations have shown that $\mathrm{Pu}$ in materials with higher hydrogen density than water has a lower minimum critical mass than $\mathrm{Pu}$ in water (530 $\mathrm{g} \mathrm{Pu}$ ). In particular, polyethylene as a moderator results in a minimum critical mass of $360 \mathrm{~g} \mathrm{Pu}$ (Thompson 1977).

Polyethylene is commonly discarded in TRU waste as bags, gloves, or bottles. The normal storage of these items results in a low density of modera. tor in the drum, but heating can cause the polyethylene to melt, resulting in 
a potentialiy near-optimum distribution of plutonium in polyethylene. This is an example of a subcritical system potentially becoming a critical system with the addition of heat.

Plutonium in materiais with higher hydrogen density than water has a lower minimum critical mass than $\mathrm{Pu}$ in water (Thompson 1977). Thus, the minimum critical areal concentration for plutonium decreases to $2.4 \mathrm{~kg} / \mathrm{m}^{2}$ for a polyethylene-reflected system. The safe operating 1 imit becomes $1.1 \mathrm{~kg} / \mathrm{m}^{2}$ $\left(45 \%\right.$ of $\left.2.4 \mathrm{~kg} / \mathrm{m}^{2}\right)$ when large quantities of hydrogenated organics 1ike polyethyiene are present in drums or other waste containers.

\section{PLUTONIUM MASS AND AREAL CONCENTRATION LIMITS FOR ISV}

The minimum critical mass is that mass of plutonium required to reach a critical configuration under optimized conditions. The minimum critical areal concentration is the minimum plutonium mass per unit area required to achieve criticality assuming a homogeneous plutonium distribution within a slab but varying the slab thickness and plutonium concentration within the slab.

Critical limits for Hanford soil that contains Pu have been calculated (Ridgway and Carter 1972). The minimum critical mass in fully saturated soil (the Pu was assumed to contain $3 \mathrm{wt} \%{ }^{240} \mathrm{Pu}$ ) is given in Table 9 for various conditions.

The most extreme set of conditions expected for minimum critical mass of plutonium in soil is ful? water-reflected plutonium ( $3 \mathrm{wt} \%{ }^{240} \mathrm{Pu}$ ) in fully saturated, $40 \%$ void volume soil. Under these conditions, the minimum critical mass is $1.7 \mathrm{~kg} \mathrm{Pu}$.

TABLE 9. Minimum Critical Mass of Plutonium in Water-Saturated Soi? (Ridgway and Carter 1972)

\begin{tabular}{lcc} 
& \multicolumn{2}{c}{ Minimum Critical Mass, kg Pu } \\
\cline { 3 - 3 } Reflection & $\frac{30 \mathrm{Vol} . \% \mathrm{Pu}-\mathrm{H}_{2} \mathrm{O}}{40 \mathrm{Vol} . \% \mathrm{Pu}_{-} \mathrm{H}_{2} \mathrm{O}}$ \\
Unreflected & 3.1 & 3.0 \\
l in. $\mathrm{H}_{2} \mathrm{O}$ Reflected & 2.2 & 2.3 \\
Full water Reflected & 2.4 & 1.7
\end{tabular}


In the ISV process, water will be removed and density will be increased. This actually causes the Pu minimum critical mass to increase. For the totally dry case the minimum critical mass would be that of a dry sphere of either $\mathrm{Pu}$ metal or $\mathrm{PuO}_{2}$. The subcritical 1 imit for a water-reflected metal sphere is around $5.0 \mathrm{~kg}$ for $\mathrm{Pu}$; for an oxide sphere it is $10.2 \mathrm{~kg} \mathrm{Pu}(11.5 \mathrm{~kg}$ oxide) (ANSI/ANS-8.1-1983).

The minimum critical areal concentration for Pu-soil mixtures is about $2.9 \mathrm{~kg} \mathrm{Pu} / \mathrm{m}^{2}$. The concentration at which this occurs is about $8 \mathrm{~g} \mathrm{Pu} / \mathrm{L}$ for an infinite slab about $14 \mathrm{in.} \mathrm{thick.} \mathrm{As} \mathrm{this} \mathrm{slab} \mathrm{dries,} \mathrm{the} \mathrm{areal} \mathrm{concentration}$ will increase.

The criticality safety factor for ISV was set at 33\%. Thus, operating limits for ISV will be met if the site to be vitrified contains a total Pu mass less than $0.6 \mathrm{~kg}$ Pu ( $33 \%$ safety factor applied to $1.7 \mathrm{~kg}$ Timit) or has an areal concentration of less than $1.0 \mathrm{~kg} \mathrm{Pu} / \mathrm{m}^{2}$ (33\% safety factor applied to $2.9 \mathrm{~kg} / \mathrm{m}^{2}$ limit) with no possibility of concentration. The areal concentration limit is $0.8 \mathrm{~kg} / \mathrm{m}^{2}$ when large quantities of hydrogenated organic materia]s such as polyethylene are present with $\mathrm{Pu}$ in waste drums or other highintegrity containers (Oma et al. 1983). 


\section{STARTER PATH ISSUES}

To establish conductivity between electrodes and initiate the melt in an ISV experiment, a path of conductive material must connect the electrodes. This starter path is designed to sustain conductivity and transfer heat to the surrounding soil until the soil itself becomes molten. The geometry, composition, and amount of material in the path are factors in an effective startup.

\section{RANGES OF STARTER PATHS USED}

A variety of materials and compositions have been used for ISV starter paths, with varying degrees of effectiveness. Through these experiences, a preferred material has been selected and a path size and configuration for each size system is recommended.

\section{Composition}

Starter materials used in early ISV experiments included graphitesoaked Fiberfrax rope, nickel/chromium wire, pure graphite powder, a $65 \%$ graphite $/ 35 \%$ soil mixture, and a $65 \%$ graphite $/ 35 \%$ glass frit mixture. The $65 \%$ graphite/ $35 \%$ frit (by volume) mixture was selected as the standard starter material. The relatively lower melting temperature of the frit aids in sustaining conductivity.

In an effort to ensure conductivity, $100 \%$ graphite has been used around the electrodes; in at least one test (PS-INEL-1A) the material burned too rapidly, leaving a void around the electrodes and resulting in a loss of conductivity. To correct this, the current recommended composition for starter material around the electrodes is pure graphite on the bottom half of the depth covered by the $65 \% / 35 \%$ mixture (Figure $2 a$ ).

\section{Configuration}

Starter paths for early tests were laid in open trenches. Later, a decision was made to cover the path with soil. This was done to allow $100 \%$ heat transfer and reduce the airborne particulate burden to the off-gas system. 


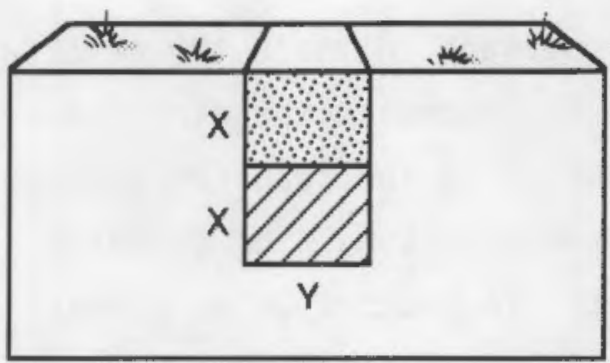

(a)

Dimensions, in.

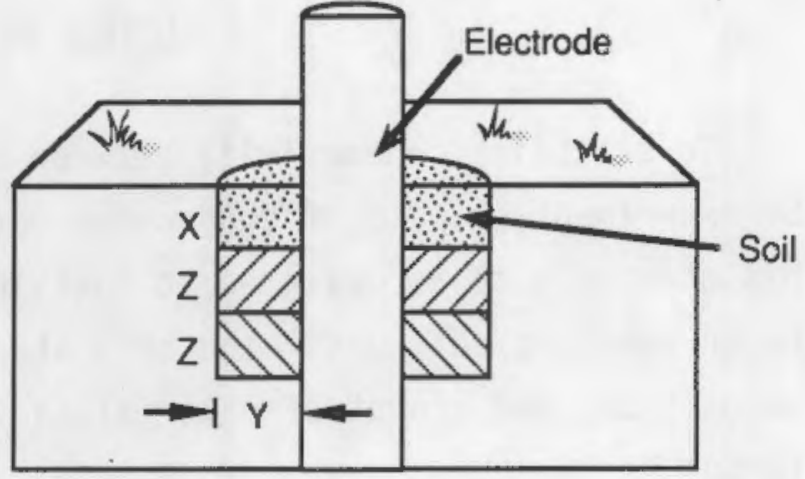

(b)

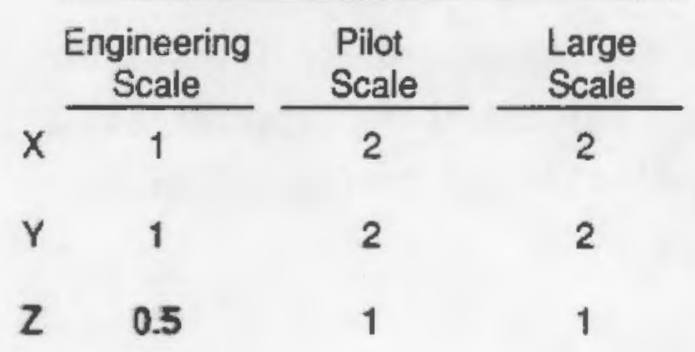

R9004251

FIGURE 1. Cross-sectional View of Starter Path. A) trench between electrodes; B) trench around electrode.

A square path is generally laid in the bottom of the trench. This allows heat transfer at a rate near the ideal provided by a cylindrical path. It is important that the trench be level. If the path is laid on a grade, the molten material could flow to the low spots, possibly causing a break in conductivity between the electrodes.

In recent tests, sand was used as a media for constructing the starter path. A common construction grade sand is placed in the area between the electrodes to a depth 2 in. greater than the starter path trench. The use of sand allows for a form to be used to construct a uniform, symmetrical starter path resulting in a balanced startup. The sand is also helpful to fill voids in the existing soil and provide a level startup area. 
The starter material for bench-scale tests (two electrodes; 4 to 6 in. between electrodes) is typically laid in a 1 in. by 1 in. path in a trench between the two electrodes.

The starter path for bench-scale tests (four electrodes in a square array; 9 to 12 in, between electrodes) is laid from one electrode to the next to form a square, and from corner to corner along the two diagonals to form an " $X$ " through the melt area.

The path in most engineering-scale tests is 1 in. by 1 in. Typical startup time is approximately 1 h (e.g., ES-116B, ES-0ttawa). A larger path, $1.5 \mathrm{in}$. deep by 2 in. wide, was used in ES-INEL-1 through -4 . Startup times in these tests ranged from $2.5 \mathrm{~h}$ (ES-INEL-2) to $10.7 \mathrm{~h}$ (ES-INEL-4).

The dimensions of the starter path in pilot-scale and large-scale experiments have ranged from 2 in. by $2 \mathrm{in}$. to roughly 4 in. by 4 in. Because trenches have been formed by hand, the shape was not always uniform and was dependent on soil type. Recently developed methods for constructing trenches with forms and wetted sand result in.greater uniformity. For example, in the 116-B large-scale test, a 2 in. $x 4$ in. tubular steel form was placed between the electrodes, and sand was poured around the form. Sufficient water was then added to the sand so that the forms could be removed without the sand collapsing into the trench. Starter material was then placed in the trench and the trench covered with soil.

\section{CURRENT PREFERRED PATHS}

Bench- and engineering-scale paths are 1 in. deep and 1 in. wide with 1 in. of sand completely covering the path. The cross-section of the path illustrated in Figure $2 a$ includes dimensions for each scale.

One-half in. of pure graphite is placed in the bottom of a 1-in. Wide trench around each electrode. The pure graphite is covered by $0.5 \mathrm{in}$. of graphite starter material and $1 \mathrm{in}$. of sand (Figure 2b). The path for engineering scale tests is laid in the typical square and " $X$ " patterns between the electrodes. 
Pilot and large-scale paths are laid by preparing 4 in. deep and 2 in. wide trenches between the electrodes in the typical " $X$ " and square patterns. The $65 \%$ graphite $/ 35 \%$ glass frit (by volume) mixture is placed 2 in. deep in the bottom of the trenches (Figure 2a).

Around each electrode a 1 -in.-deep layer of pure graphite is placed in a 4 in. deep by 2 in. wide trench. A l-in. layer of $65 \%$ graphite $/ 35 \%$ glass frit is then added, followed by a 2 -in. cover layer of sand (Figure $2 b$ ).

\section{ALLOWABLE DEVIATIONS}

The starter path must contain enough material to ensure conductivity. The smallest path used, 1 in. by 1 in., has been adequate for bench- and engineering-scale units. Smaller amounts could be used if desired, with some increased risk of loss of conductivity (starter path blowout).

Additional starter material results in longer startup times and 1 arger amounts of particulate in the off-gas system. In ES-INEL-4 the $1.5 \mathrm{in}$. by 2 in. path resulted in a $10.7 \mathrm{~h}$ startup time. The additional amount of starter material (a $150 \%$ excess) and longer startup time did not result in temperatures that could have adverse effects on waste in the melt. Temperature at startup (after $10.7 \mathrm{~h}$ ) was $100^{\circ} \mathrm{C}$ at $12 \mathrm{in.}$ below surface.

The impact of changing the starter path, in terms of frit volume used, has not been researched as a separate topic. However, from the information available, deviations of $\pm 50 \%$ in path volume should be acceptable. The dimensions of the cover layer of soil is judged to be of lesser importance.

\section{$\underline{\text { RESTART }}$}

Laying the starter path under restart conditions is difficult because of the hazardous working environment (heat and off gas). The soil is hot and very dry, and the worker must wear a mask and bulky protective clothing, making trench formation difficult. In addition, hot glass needs to be broken up and removed or covered. All of these factors make volumetric control of materials difficult. The current preferred approach is to let the area cool to 
allow safe worker entry, cover with wet sand (4 to 6 in.), form trenches in the wet sand using forms, and $f i 11$ the trenches with the materials per Figure 2.

\section{SUMMATION}

The preferred starter path for each system is effective when properly prepared. Variations in the composition of the material, amount of material, and configuration of the path are tolerable to some degree, but some variations have resulted in long startup times (more material) or starter path blowout (less material). 



\section{REFERENCES}

AEC. 1974. Reactor Safety Study, Appendix III, WASH-1400, Atomic Energy Commission, Washington, D.C.

ANSI/ANS-8.15, "Nuclear Criticality Control of Special Actinide Elements." American National Standard 8.15, American Nuclear Society, LaGrange Park, Illinois.

ANSI/ANS-8.1 1983, "Nuclear Criticality Safety in Operations with Fissionable Materials Outside Reactors." American National Standard 8.1, American Nuclear Society, LaGrange Park, I1 inois.

Barin, 1., and 0. Knocke. 1973. Thermochemical Properties of Inorganic Substances, Springer Verlog, New York.

Barin, I., 0. Knocke, and 0. Kubaschewski. 1977. Thermochemical Properties of Inorganic Substances, Supplement." Springer Verlog, New York.

Blyckert, W. A., and R. D. Carter. 1980. Criticality Parameters of 55-Gallon Waste Drum Arrays. RHO-SA-183, Rockwell Hanford Operations, Richland, Washington.

Buelt, J. M., and J. G. Carter. 1986. Description and Capabilities of the Large-Scale In Situ Vitrification Process. PNL-5738, Pacific Northwest Laboratory, Richland, Washington.

Buelt, J. M., et a1. 1987. In Situ Vitrification of Transuranic Waste: An Updated Systems Evaluation and Applications Assessment. PNL-4800 Supp 1. 1, Pacific Northwest Laboratory, Richland, Washington.

Clayton, E. D. 1979. "Anomalies of Nuclear Criticality." PNL-SA-4868, Rev. 5, Pacific Northwest Laboratory, Richland, Washington.

Flowtow, H. E., and M. Teltenbaum. 1981. J. Chem. Phys. 74:5269.

Jones, G. L. 1986. Safety Analysis Documentation Preparation Coordination, Review and Approval Process. SD-SQA-AR-002, RockwelT Hanford Operations, Richl and, Washington.

Kennedy, W. E., Jr., R. L. Aaberg, B. A. Napier, and 239 K. Soldat. 1982. Transuranic Advanced Disposal Systems: Preliminary 239 Pu Waste Disposal Criteria for Hanford. PNL-4254, Pacific Northwest Laboratory, Richland, Washington.

Koegler, S. S. 1987. Disposal of Hazardous Wastes by In Situ Vitrification, PNL-6281, Pacific Northwest Laboratory, Richland, Washington. 
Mudge, L. K., D. G. Ham, S. L. Weber, D. H. Mitche11. 1980, 0xygen/Steam Gasification of Wood. PNL-3353, Pacific Northwest Laboratory, Rich]and, Washington.

Napier, B. A. 1982. A Method for Determining "Allowable Residual Contamination Levels" of Radionuclide Mixtures in Soil. PNL-3852, Pacific Northwest Laboratory, Richland, Washington.

NWTP. 1982a. Nuclear Waste Treatment Program Monthiy Report for March 1982. Pacific Northwest Laboratory, Richland, Washington.

NWTP. 1982b. Nuclear Waste Treatment Program Monthly Report for Apri 1982. Pacific Northwest Laboratory, Richland, Washington.

NwTP. 1982c. Nuclear Waste Treatment Program Monthly Report for May 1982.

Pacific Northwest Laboratory, Richland, Washington.

NWTP. 1982d. Nuclear Waste Treatment Program Monthly Report for June 1982. Pacific Northwest Laboratory, Richland, Washington.

NWTP. 1982e. Nuclear Waste Treatment Program Monthly Report for August 1982. Pacific Northwest Laboratory, Richland, Washington.

Oma, K. H., D. R. Brown, J. L. Buelt, V. F. Fitzpatrick, K. A. Hawiey, G. B. Mellinger, B. A. Napier, D. J. Silviera, S. L. Stein, and C. L. Timmerman. 1983. In Situ Vitrification of Transuranic Wastes: Systems Evaluation and Applications Assessment. PNL-4800, Pacific Northwest Laboratory, Richland, Washington.

Oma, K. H., R. K. Farnsworth, and J. M. Rusin. 1982. In Situ Vitrification: Application Analysis for Stabilization of Transuranic Waste. PNL-4442, Pacific Northwest Laboratory, Richland, Washington.

Owens, K. W. 1981. Existing Data on the 216-2 Liquid Waste Sites. RHO-LD-NY, Rockweli Hanford Operations, Richland, Washington.

Ridgway, K. R., and R. D. Carter. 1972. Criticality Prevention Parameters of Plutonium in Soils. ARH-2622, Atlantic Richfield Hanford Company, Richland, Washington.

Rockwell Hanford Operations. 1978. Radiological Controls. RHO-MA-220, Rockwel] Hanford Operations, Richland, Washington.

Schonfeld, F. W. 1961. "Plutonium-Iron Phase Diagram," In The Metal Plutonium, A. S. Coffinberry and W. N. Miner, eds., University of Chicago Press, Chicago. RHD-MA-220, Rockwell Hanford Operations, Richland, Washington.

Swain, A. D., and H. E. Guttman. 1983. Handbook of Human Reliability Analysis with Emphasis on Nuclear Power Plant Applications. NUREG-CR-1278, U.S. Nuclear Regulatory Commission, Washington, D.C. 
Thompson, J. K. 1977. "Technical Note - Minimum Critical Mass of PlutoniumPolyethylene System Found to Be Significantly Lower than Plutonium-Water System," Nuclear Technology 32:235-236.

U.S. DOE, 1981. Environmental Protection, Safety, and Health Protection Programs for DOE Operations. Order 5480.1A, Washington, D.C.

Vesely, W. E., F. F. Goldberg, N. H. Roberts, and D. F. Haas1. 1981. Fault Tree Handbook. NUREG-0492, U.S. Nuclear Regulatory Commission, Washington, D.C.

Wicks, C. E., and F. E. Black. 1963. "Thermodynamic Properties of 65 Elements -- Their Oxides, Halides, and Nitrides." Bureau of Mines, U.S.

Department of Interior, Bullet in 605.

Wiege1, F., J. J. Koty, and G. T. Scaborg. 1986. The Chemistry of the Actinide Elements. 2nd Edition, Volume 1, eds. J. J. Koty, G. T. Scaborg, and L. R. Moress. Chapman and Ha I1, New York.

Zimmer, W. H. 1973. Interim Report: Sampling Techniques and Analysis of 219-Z-9 Covered Trench. ARH-2752, Rockwell Hanford Operations, Richland, Washington. 
.

. 


\section{DISTRIBUTION}

No. of

Copies

OFFSITE

I2 DOE/Office of Scientific and Technical Information

T. B. Hindman, DP-12

DOE Office of Defense Programs GTN

Washington, DC 20545

H. F. Walter, EM-343

DOE Office of Waste Operations GTN

Washington, DC 20545

5 DOE Office of Environmental

Restoration and Waste Management

Forrestal Building

Washington, DC 20585

ATTN: C. R. Cooley, EM-55

T. D. Anderson, EM-442

C. Frank, EM-50

S. Prestwich, EM-52

S. P. Mathur, EM-54

DOE Idaho Operations Office

785 DOE Place

Idaho Falls, ID 83402

ATTN: M. W. Shupe

W. T. Goldston

DOE Savannah River Operations Office

P. O. Box A

Aiken, SC 29801

3 Battelle Memorial Institute

505 King Avenue

Columbus, $\mathrm{OH} 43201$

ATTN: W. A. Carbeiner

R. A. Nathan

Technical Library
No. of

Copies

\author{
R. Vocke \\ Los Alamos Nationa] Laboratory \\ P.0. Box 1663 \\ Los Alamos, NM 87545 \\ 2 Oak Ridge National Laboratory \\ P.0. Box Y \\ Oak Ridge, TN 37830 \\ ATTN: S. B. Garland \\ B. P. Spalding \\ 2 Sandia Laboratories \\ P.0. Box 5800 \\ Albuquerque, NM 87185 \\ ATTN: R. W. Lynch \\ Technical Library \\ J. T. Sweeney \\ DOE Oak Ridge Operations \\ Oak Ridge, TN 37830 \\ 6 EG\&G Idaho \\ P.0. Box 1625 \\ Idaho Falls, ID 83415 \\ ATTN: R. A. Callow \\ R. K. Farnsworth \\ S. K. Merrill (2) \\ W. J. Quapp \\ D. Nickelson
}

2 Westinghouse Savannah River Company

Savarnah River Site

Aiken, SC 29801

ATTN: J. Haselow

J. Steele 
No. of

Copies

\section{ONSITE}

5 Geosafe Corporation Kirkland Park Place 303 Park P1ace, Suite 126

Kirkland, WA 98033

ATTN: B. E. Campbel]

J. G. Carter

V. F. FitzPatrick

S. C. Liikala

C. L. Timmerman

5 DOE Richland Operations Office

E. A. Bracken, A6-95

G. J. Bracken, A6-80

P. K. Clark, A6-80

P. F. Dunigan, A6-95

M. J. Furman, A6-80

11 Westinghouse Hanford Company

K. D. Bommer, H5-49

B. J. Broomfield, N3-12

R. E. Lerch, B2-35

H. E. McGuire, B2-35

R. C. Roal, S6-08

R. J. Roberts, N3-13

J. L. Scott, R2-87

J. A. Swenson, G6-45

D. A. Turner, RI-10

D. D. Wodrich, R1-48

R. D. Wojtasek, B2-15
No. of

Copies

35 Pacific Northwest Laboratory

T. Bergsmann, P7-41

W. F. Bonner, P7-44

J. L. BueTt, P7-44

H. C. Burkholder, P7-41

R. D. Gibby, P7-44

P. J. Gouge, P7-4l (5)

D. K. Hitiiard, K2-12

J. T. Jeffs, P7-4I

C. H. Kindle, P7-44 (5)

S. S. Koegler, P7-44

W. L. Kuhn, P7-I4

J. L. McElroy, P7-46

M. C. Miller, P7-41

M. E. Peterson, P7-44

T. D. Powe 11, P7-44

R. L. Richardson, P7-44

J. W. Shade, P8-37

R. S. Skeen, P7-41

C. M. Smith, P7-43

J. A. Stottlemyre, K6-78

L. E. Thompson, P7-44

Publishing Coordination

Technical Report Files 